\title{
Research Article \\ MITIGATION OF SALINITY STRESS EFFECT BY PLANT GROWTH REGULATORS AND NUTRIENTS IN BLACK GRAM UNDER INVITRO CONDITION
}

\author{
SIVAKUMAR R. AND JAYA PRIYA S.
}

Department of Crop Physiology, Tamil Nadu Agricultural University, Coimbatore, 641003, Tamil Nadu

*Corresponding Author: Email- sivatnau14@gmail.com

\author{
Received: February 23, 2018; Revised: February 25, 2018; Accepted: February 26, 2018; Published: February 28, 2018
}

\begin{abstract}
An experiment was conducted to mitigate the impact of salinity stress on blackgram through seed soaking with plant growth regulators viz., jasmonic acid (50 $\mu \mathrm{M})$, gibberellic acid (10 mM), benzyl amino purine (50 ppm),ascorbic acid (100 ppm), salicylic acid (100 ppm) and nutrients like $\mathrm{KCl}(1 \%)$ and $\mathrm{CaCl} 2(0.5 \%)$ under invitro condition. Salinity was imposed at $125 \mathrm{mM} \mathrm{NaCl}$ and seeds of TNAU (Blackgram) $\mathrm{CO} 6$ were used in this study. The results revealed that salt stress caused detrimental effect on seed germination and seedling growth. Among the ameliorants, jasmonic acid showed significantly highest germination percentage of 86.50, vigour index of 771.58 and stress tolerance index of 39.38 per cent. Salinity reduced the root length up to 71.93 per cent compared to absolute control. The highest root length of $2.92 \mathrm{~cm}$ was registered by jasmonic acid followed by ascorbic acid $(2.36 \mathrm{~cm})$ which is on par with $\mathrm{KCl}(2.31 \mathrm{~cm})$. However, salicylic acid recorded the least sodium/potassium ratio (0.320) followed by $\mathrm{KCl}(0.328), \mathrm{CaCl}_{2}(0.329)$ and jasmonic acid (0.332). Jasmonic acid (5.55) and salicylic acid (5.85) showed their supremacy on increased catalase activity which protect the plant under saline condition.
\end{abstract}

Keywords- Jasmonic acid, salicylic acid, root length, vigour index, $\mathrm{Na}^{+} / \mathrm{K}^{+}$ratio, blackgram.

Citation: Sivakumar R. and Jaya Priya S. (2018) Mitigation of Salinity Stress Effect by Plant Growth Regulators and Nutrients in Blackgram under in-vitro Condition. International Journal of Agriculture Sciences, ISSN: 0975-3710 \& E-ISSN: 0975-9107, Volume 10, Issue 4, pp.-5199-5202.

Copyright: Copyright@2018 Sivakumar R. and Jaya Priya S. This is an open-access article distributed under the terms of the Creative Commons Attribution License, which permits unrestricted use, distribution and reproduction in any medium, provided the original author and source are credited.

\section{Introduction}

Pulses are important next only to food grains in terms of area, production and productivity in Indian Agriculture. Blackgram (Vigna mungo Linn.) is one of the most important prized pulse crops grown in almost all parts of the country. It contains protein, vitamins and richest source of phosphorus among pulses which are very essential for human beings. Due to its nutritional quality, blackgram called as "King of Pulses" [1].

Salinity is one of the most urgent problems of farmers in the world. Nearly $20 \%$ of the world's cultivated area and nearly $50 \%$ of the world's irrigated lands are affected by salinity [2].In India, about 6.73 Mha land is salt affected [3]. Salinity stress is a serious problem in arid and semi-arid tropics and recognized as major constraint in the crop production where $50 \mathrm{mM} \mathrm{NaCl}$ can cause yield losses more than 70 per cent [4]. Blackgram is very sensitive to salinity especially at early stage of growth and affects the ability to utilize water which causes reduction in germination and growth rate as well as plant metabolic processes [5]. Salt stress causes physiological drought which is responsible for delayed seed germination, seedling establishment and reduced growth and yield of any crop [6]. To overcome this problem, salt tolerance cultivars and seed treatments with PGRs and nutrients can be used as alternative strategies [7]. External applications of PGRs optimize physical metabolic conditions for seed germination [8], when endogenous hormones affected by environmental stress. Under high salt concentrations, natural hormones may be suppressed and seed soaking with PGRs supplies sufficient hormones for normal growth. Incorporation of PGRs during pre-soaking, priming and nutrient treatments in many vegetable crops have improved seed performance, nutrient reserves through increased physiological activities and root proliferation and yield under stress condition [9].

Exogenous application of Jasmonic acid improved recovery of salt-stressed rice seedlings. Jasmonic acid content in salt sensitive cultivar plants was lower than salt-tolerant cultivar plants [10]. Exogenous application of salicylic acid increases the survival rate, shoot growth and photosynthesis in tomato and barley plants during salt stress conditions [11]. Ascorbic acid is one of the most effective growth regulators and protecting biologically important macromolecule from abiotic stress [12]. Hence, the present study is conceived to mitigate the salinity stress effect by investigate the effects of PGRs and nutrients on blackgram through presoaking method.
Materials and Methods
The experiment was carried out in petridishes under in-vitro condition. The petridishes were sterilized using 0.01 per cent $\mathrm{HgCl}_{2}$ and 70 per cent ethanol and finally washed with distilled water. The petridishes were cleaned thoroughly with a cotton swab. The salinity was created by using $\mathrm{NaCl}$ at $125 \mathrm{mM}$ concentration.
PGRs and nutrient solutions were prepared separately includes jasmonic acid (50 $\mu \mathrm{M})$, gibberellic acid $(10 \mathrm{mM})$, benzyl amino purine $(50 \mathrm{ppm})$, ascorbic acid (100 $\mathrm{ppm})$, salicylic acid (100 ppm) and nutrients like $\mathrm{KCl}(1 \%)$ and $\mathrm{CaCl}_{2}(0.5 \%)$. Seeds of blackgram variety TNAU (Blackgram) $\mathrm{CO}$ 6weresoaked in above mentioned plant growth regulators and nutrients solutions for $12 \mathrm{hrs}$. After, the seeds were dried under shade for 4 hrs. Later the treated seeds were placed on filter paper in each petridish separately, untreated seeds in control and absolute control. The petridishes were kept in laboratory under room temperature. The seeds were allowed to germinate by pouring $125 \mathrm{mM} \mathrm{NaCl}$ solution of $10 \mathrm{~mL}$ each once in three days. Distilled water was used for maintaining the absolute control and experiment was carried out with one genotype imposed with nine treatments, replicated thrice and statistics of completely randomized block design.

The germination was recorded at every 24 hours interval up to 15 days. Seeds 
were considered germinated when the radical was at least $2 \mathrm{~mm}$ long. Finally, germination percentage was calculated by using following formula and expressed as per cent. Germination per cent $=$ (Number of germinated seeds/Number of seeds kept for germination) $X 100$. On $15^{\text {th }}$ DAS, seedlings from each replication were carefully removed at random. Root length of the seedlings was measured from the base of the stem to the tip of the longest root and expressed as $\mathrm{cm}$. Length of shoot was measured from the collar region to the tip of the longest leaf and expressed as $\mathrm{cm}$.

Five seedlings were chosen randomly and the shoot dry weight of the seedling was measured after kept in hot air oven at $80^{\circ} \mathrm{C}$ for $48 \mathrm{hrs}$. Vigour index of the seedlings was calculated using the following formula [13]. Vigour Index $=$ (Shoot length + Root length) $x$ germination percentage. Stress tolerance index (STI) was calculated using the following formula [14] and expressed as per cent.

\section{STI = (Vigour index of the treated seedling / Vigour index of the control seedling) $X$} 100.

Catalase activity in seedling was determined by titration method using potassium permanganate [15] and expressed as $\mu \mathrm{g} \mathrm{H}_{2} \mathrm{O}_{2} \mathrm{~g}^{-1} \mathrm{~min}^{-1}$. Sodium and potassium contents in the seedlings were estimated by using atomic absorption spectrometer and $\mathrm{Na}^{+} / \mathrm{K}^{+}$ratio was calculated. The data on various parameters were analyzed statistically [16].

\section{Result and Discussion}

Seed germination is one of the most fundamental and vital phases of growth cycle that determine plant establishment and the yield of the crops [17]. Germination percentage was reduced under saline condition. In the present study, 34.67 per cent reduction of germination occurred under saline condition. This reduction might be due to, salinity creating osmotic stress which prevents the water uptake and by toxic effects of ions on embryo viability as well as oxidative damage. Current result was coinciding with the earlier finding reported that the increased salinity concentration progressively decreased the germination percentage of blackgram [18]. Under salt stress condition germination percentage reduced up to 40 per cent in greengram [19]. Sodium ion could be a toxic factor that results in reduced germination because it causes impaired water uptake, secretion of hormones and modifies the activity of enzyme such as malate dehydrogenase and glucose 6-phosphate dehydrogenase [20].

Pretreatment of seeds with different type of plant growth regulators is much effective in alleviating stress effects of salinity on the plants at different stages especially at early stage and it has been shown to improve seed germination under salt stress [21]. In this present investigation, jasmonic acid restores the salinity stress and increases the germination percentage up to 33.08 per cent followed by gibberellic acid (31.53\%) compared to control [Table-1]. Similar result was noticed earlier and stated that, methyl jasmonates increases germination percentage of Ocimum basilicum under saline conditions [22]. The positive effect of jasmonic acid on germination might be due to involvement in the loosening of seed coat for water uptake and activation of gibberellic acid.GA $\mathrm{A}_{3}$ enhanced the oxygen uptake and increased a-amylase activity, efficiency of mobilizing nutrients from the cotyledons to the embryonic axis [23] resulting increased germination [19]. The present study confirms the earlier findings.

Table-1 Effect of PGRs and nutrients on germination and seedling characters of blackgram under salinity.

\begin{tabular}{|l|c|c|c|}
\hline \multicolumn{1}{|c|}{ Treatments } & $\begin{array}{c}\text { Germination } \\
(\%)\end{array}$ & $\begin{array}{c}\text { Root } \\
\text { length }(\mathrm{cm})\end{array}$ & $\begin{array}{c}\text { Shoot length } \\
(\mathbf{c m})\end{array}$ \\
\hline Absolute control (Without salinity) & 99.50 & 6.52 & 13.07 \\
\hline Control (Salinity) & 65.00 & 1.83 & 3.62 \\
\hline Jasmonic acid $(50 \mu \mathrm{M})$ & 86.50 & 2.92 & 6.00 \\
\hline Gibberellic acid $(10 \mathrm{mM})$ & 85.50 & 2.19 & 6.14 \\
\hline Benzyl amino purine (50 ppm) & 83.00 & 1.85 & 3.90 \\
\hline Ascorbic acid $(100 \mathrm{ppm})$ & 75.33 & 2.36 & 4.75 \\
\hline Salicylic acid $(100 \mathrm{ppm})$ & 80.00 & 2.05 & 5.05 \\
\hline $\mathrm{KCl}(1 \%)$ & 75.35 & 2.31 & 5.65 \\
\hline $\mathrm{CaCl}(0.5 \%)$ & 70.00 & 1.83 & 4.75 \\
\hline SEd & 1.87 & 0.05 & 0.12 \\
\hline $\mathrm{CD}(\mathrm{P}=\mathbf{0 . 0 5})$ & 3.93 & 0.10 & 0.26 \\
\hline
\end{tabular}

Root and shoot lengths are important parameters that determine the growth and development of plants. Measurement of root length is the most important indicator of salt stress because roots are in direct contact with the salt. The salinity reduced the root length up to 71.93 per cent compared to absolute control. It might be due to toxic effects of $\mathrm{NaCl}$ and decreased turgor and cell elongation caused by physiological drought.

In this present investigation, salinity reduced the shoot length up to 64 per cent. It is corroborated with the earlier findings reported that the root length was reduced up to 60 per cent and shoot length was 35.7 per cent by salinity in greengram [19]. This reduced shoot length by salinity might due to inhibitory effects of salt on cell division in the growing points. Similar result was found earlier and explained that salt stress inhibited the efficiency of translocation and assimilation of stored materials and might have caused a reduction in shoot growth [24]. Under saline condition, gibberellic acid treated seeds showed increased the shoot length of 69.61 per cent followed by jasmonic acid (65.74\%) compared to control [Table-1]. The present study confirmed with the earlier findings reported that the root length was increased by $\mathrm{GA}_{3}$ treatment by 25.6 per cent [19]. This might be due to enhanced $\mathrm{Ca}$ concentration and restored membrane integrity in shoot. These data agree with the finding [25] stated that pre-soaking with gibberellic acid increased the germination percentage, shoot and root length in wheat under saline condition. Similar result was observed earlier [26] and reported that, both root and shoot lengths were reduced with increased $\mathrm{NaCl}$ concentration, but the root was more damaged compared to shoots. Root was more sensitive than shoot under saline condition. In this present investigation, jasmonic acid treated seeds improved the root length up to 59.56 per cent compared to control. This might be due to jasmonic acid induced cell division process under salinity. Salt stress reduced the root length up to 75.27 per cent in pepper while methyl jasmonic acid treatments significantly minimized the reduction percentage [27].

Salt stress caused significant reduction in shoot dry weight. This reduction of shoot dry weight might be due to turgor limitation leads to limiting extension growth. The salinity reduced the shoot dry weight up to 44.33 per cent compared to absolute control. This observation was supported and reported that salinity decreases growth parameters such as fresh and dry weights of plants [21]. In this present study, jasmonic acid increases the shoot dry weight up to 32.76 per cent [Fig-2]. This is probably by increasing the efficiency of water uptake. Gibberellic acid also significantly increased the shoot dry weight $(24.29 \%)$ under saline condition. Pre-soaking with $\mathrm{GA}_{3}$ increases the germination potential, fresh and dry matter yield in wheat under saline condition [25].

Vigour index of the seedling is well established parameter to assess stress tolerant capacity of the crop. The vigour index was significantly inhibited by salinity stress and improved by the PGRs and nutrients. In the present study, around 82 per cent of vigour index reduction was recorded by salinity. Among the treatments, jasmonic acid registered highest vigour index (771.58) when compared to control (354.25) [Fig-1]. All the treatments showed improved vigour index as compared to non-treated seeds which was due to increased germination, shoot and root length of seedlings by PGRs and nutrients.

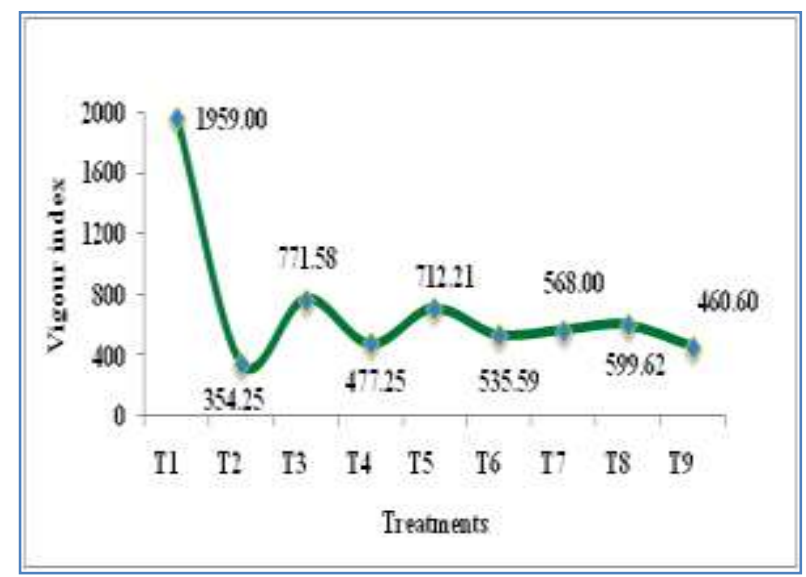

Fig-1 Effect of PGRs and nutrients on vigour index of blackgram under salinity 


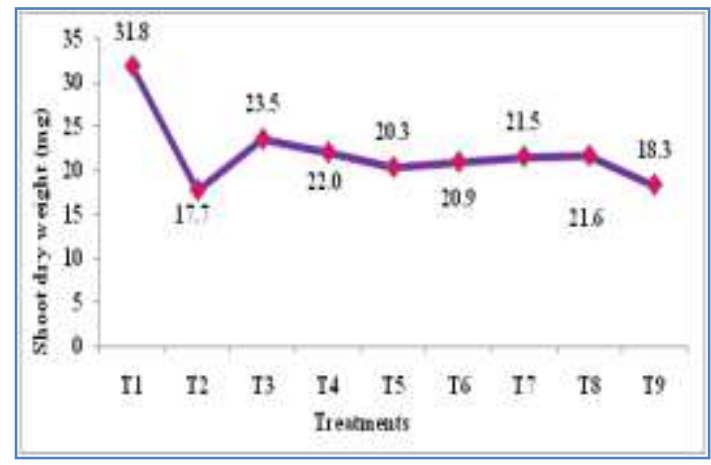

Fig-2 Effect of PGRs and nutrients on shoot dry weight of blackgram under salinity

$\mathrm{T}_{1}$ : Absolute control (Without salinity); $\mathrm{T}_{2}$ : Control (Salinity); $\mathrm{T}_{3}$ : Jasmonic acid (50 $\left.\mu \mathrm{M}\right) ; \mathrm{T}_{4}$ Gibberellic acid (10 mM); T5: Benzyl amino purine (50 ppm); T6: Ascorbic acid (100 ppm); $\mathrm{T}_{7}$ : Salicylic acid (100 ppm); $\mathrm{T}_{8}: \mathrm{KCl}(1 \%) ; \mathrm{T}_{9}: \mathrm{CaCl}_{2}(0.5 \%)$.

In the present investigation, $\mathrm{Na}^{+} / \mathrm{K}^{+}$ratio was increased under salinity while presoaking with PGRs and nutrients reduced the $\mathrm{Na}^{+} / \mathrm{K}^{+}$ratio in the seedling [Table2]. Among the PGRs and nutrients, salicylic acid registered lowest $\mathrm{Na}^{+} / \mathrm{K}^{+}$ratio (0.320) followed by $\mathrm{KCl}(0.328), \mathrm{CaCl}_{2}(0.329)$ and jasmonic acid (0.332). This might be due to enhanced calcium concentration by salicylic acid and $\mathrm{KCl}$ treatments whish restored the membrane integrity under saline conditions. Seeds soaking with salicylic acid and $\mathrm{KCl}$ reduced the $\mathrm{Na}^{+} / \mathrm{K}^{+}$ratio in green gram [19] was reported earlier. Seeds primed with $\mathrm{CaCl}_{2}$ maintaining the germination under saline conditions due to the influence of calcium on membranes [28]. Calcium protects the plants from adverse effects of salt stress and improves the growth of plants under saline conditions by decreasing $\mathrm{Na}^{+} / \mathrm{K}^{+}$ratio as found in this study. Salicylic acid reduced the $\mathrm{Na}^{+} / \mathrm{K}^{+}$ratio as compared to control under salt stress. This result is corroborated with the finding stated that exogenous salicylic acid applications inhibited $\mathrm{Na}$ accumulation, but stimulated $\mathrm{Ca}$ uptake in cucumber [29]. An increase in concentration of $\mathrm{K}$ and $\mathrm{Ca}$ in plants under salt stress could ameliorate the deleterious effects of salinity on growth and yield [30].

Table-2 Effect of PGRs and nutrients on $\mathrm{Na}^{+} / \mathrm{K}^{+}$ratio and STI of blackgram under salinity

\begin{tabular}{|l|c|c|}
\hline \multicolumn{1}{|c|}{ Treatments } & $\mathrm{Na}^{+} / \mathrm{K}^{+}$ratio & STI (\%) \\
\hline Absolute control (Without salinity) & 0.052 & - \\
\hline Control (Salinity) & 0.326 & 18.08 \\
\hline Jasmonic acid $(50 \mu \mathrm{M})$ & 0.322 & 39.38 \\
\hline Gibberellic acid $(10 \mathrm{mM})$ & 0.364 & 36.35 \\
\hline Benzyl amino purine (50 ppm) & 0.331 & 24.36 \\
\hline Ascorbic acid (100 ppm) & 0.348 & 27.33 \\
\hline Salicylic acid (100 ppm) & 0.330 & 28.99 \\
\hline $\mathrm{KCl}(1 \%)$ & 0.338 & 30.60 \\
\hline $\mathrm{CaCl}(0.5 \%)$ & 0.339 & 23.51 \\
\hline $\mathrm{SEd}$ & 0.01 & 0.49 \\
\hline $\mathrm{CD} \mathrm{(P=0.05)}$ & 0.02 & 1.03 \\
\hline
\end{tabular}

STI is a more stable character and can be considered as a useful tool to identify stress tolerant genotypes [31] and categorizing the tolerant and susceptible plants. In this present study, jasmonic acid recorded highest STI (39.38) followed by gibberellic acid (36.35) over control [Table-2]. The reason attributed for higher stress tolerance index was due to increased germination percentage and seedling height, which were not affected in PGRs and nutrients treated seeds showing tolerance to salinity stress compared to control.

Catalase is an important cellular antioxidant enzyme that nullifies the effect of $\mathrm{H}_{2} \mathrm{O}_{2}$. Higher activity of catalase decreased the $\mathrm{H}_{2} \mathrm{O}_{2}$ level in cell and increases the stability of membranes and protects the plant under any abiotic stress condition. Lower the value of hydrogen peroxide implies the higher catalase activity, and plants can withstand the abiotic stress. In this experiment, catalase activity was increased in saline condition up to 36.19 per cent compared to absolute control. Among the treatments, jasmonic acid increased the catalase activity up to 32.43 per cent followed by salicylic acid (25.64\%) over control [Fig-
3]. Jasmonic acid treatment reduces the amount of lipid peroxidation and stimulates the synthesis of antioxidant enzymes [32]. This result was supported by early findings which reported that salicylic acid regulates physiological and biochemical processes in plants and can be used as a potential growth regulator to improve plant growth under saline conditions [33].

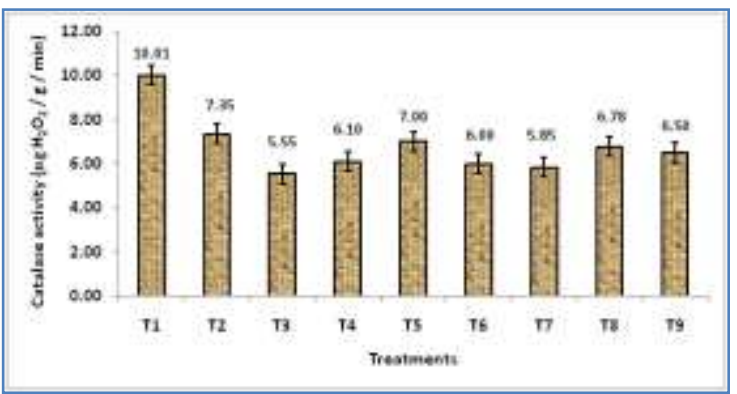

Fig-3 Effect of PGRs and nutrients on catalase activity of blackgram under salinity

$\mathrm{T}_{1}$ :Absolute control (Without salinity); $\mathrm{T}_{2}$ : Control (Salinity); $\mathrm{T}_{3}$ :Jasmonic acid $(50 \mu \mathrm{M}) ; \mathrm{T}_{4}$ : Gibberellic acid (10 mM); T5: Benzyl amino purine (50 ppm); T6: Ascorbic acid (100 ppm); $\mathrm{T}_{7}$ : Salicylic acid (100 ppm); $\mathrm{T}_{8}: \mathrm{KCl}(1 \%) ; \mathrm{T}_{9}: \mathrm{CaCl}_{2}(0.5 \%)$.

\section{Conclusion}

Presoaking of blackgram seeds with jasmonic acid $(50 \mu \mathrm{M})$ showed its supremacy for enhanced seed germination and other seedling characters under salt stress condition. Root length was improved by jasmonic acid and $\mathrm{KCl}$. In addition to salicylic acid and $\mathrm{KCl}$ decreased the $\mathrm{Na}^{+} / \mathrm{K}^{+}$ratio and jasmonic acid increased catalase activity. It is concluded that treatments with jasmonic acid $(50 \mu \mathrm{M})$, salicylic acid (100 ppm) and $\mathrm{KCl}(1 \%)$ have the ability to reduce the severity of the salinity effect and can be used as amelioration under salt stress condition.

\section{Applications of Research}

1. Mitigation technology for salinity effect on blackgram has been identified

2. Suitable PGR for alleviation of salinity impact on blackgram has been identified

\section{Research category: Crop Management}

\author{
Abbreviations \\ PGRs - Plant Growth Regulators \\ $\mathrm{GA}_{3}-$ Gibberellic acid \\ $\mathrm{KCl}$ - Potassium Chloride \\ $\mathrm{CaCl}_{2}$ - Calcium Chloride \\ DAS - Days after Sowing \\ $\mathrm{H}_{2} \mathrm{O}_{2}$ - Hydrogen Peroxide
}

Acknowledgement: The Authors would like to acknowledge the Professor and Head, Department of Crop Physiology, Tamil Nadu Agricultural University for providing Glass house, pots and labours for timely completion of Research work.

\section{*Chairperson of Research: Dr R. Sivakumar}

University: Tamil Nadu Agricultural University, Coimbatore, 641003, Tamil Nadu Research Project Name: M.Sc. Thesis - Impact of plant growth regulators and nutrients on mitigation of salinity stress effect in blackgram (Vigna mungo L.)

\section{Author Contributions}

Sivakumar Rathinavelu - Design of experiment, data analysis and interpretation and drafting the article.

Jaya Priya - Conduct the experiment, measurement of parameters and laboratory analysis.

Author statement: All authors read, reviewed, agree and approved the final manuscript 
Conflict of Interest: None Declared

Ethical approval: This article does not contain any studies with human participants or animals performed by any of the authors.

\section{References}

[1] USDA (2016) National Nutrient Database for Standard Reference Release 28.

[2] Zhu J. K. (2001) Trends in Plant Sci., 6, 66-71.

[3] Pathak K. (2000) Indian Farming, 49, 15-19.

[4] Hasanuzzaman M., Nahar K. and Fujita M. (2013) Plant response to salt stress and role of exogenous protectants to mitigate salt-induced damages. Springer, New York, NY: 25-87.

[5] Munns R. (2002) Plant Cell and Environ., 25, 239-250.

[6] Azooz M. (2009) Int. J. Agric. Bio Eng., 11, 343-350.

[7] Sadeghi H., Khazaei F., Yari L. and Sheidaei S. (2011) Arpn. J. Agric. Biol. Sci., 6, 39-43.

[8] Kabar K. (1987) Turk. J. Biol., 11, 108-117.

[9] Halmer P. (2004) Methods to improve seed performance in the field. In: Handbook of seed physiology; Application to agriculture. (Eds.): R.L. Benech-Arnold and R.A. Sanchez. The Haworth Press. New York: 125-165.

[10] Kang D.J., Seo Y.J. Lee J.D. Ishii R. Kim K.U. Shin D.H. Park S.K. Jang S.W. and Lee I.J. (2005) J. Agron Crop Sci., 191, 273-282.

[11] Stevens J., Senaratna T. and Sivasithamparam K. (2006) Plant Growth Regul., 49, 77-83.

[12] Dehghan G., Rezazadeh L. and Habibi G. (2011) Acta Biologica Szegediensis, 55, 261-264.

[13] Abdul-Baki A. and Anderson J.D. (1973) Crop Sci., 13, 630-633.

[14] Dhopte A.M. and Livera M.M. (1989) Useful Techniques for Plant Scientists, Forum for Plant Physiologists, Murly Printers, Shivnagar, Akola.

[15] Gopalachari N.C. (1963) Indian J. Exp. Biol., 1, 98-100.

[16] Gomez K.A. and Gomez A. A. (1984) Statistical procedures for agricultural research. (2nd Ed.) John Wiley and sons, NewYork, USA. p. 680

[17] Khan M.A. and Weber D.J. (2008) Ecophysiology of high salinity tolerant plants (tasks for vegetation science), 1 1 stedn. Springer, Amsterdam.

[18] Deepa B., Abraham E., Cordeiro N., Mozetic M., Mathew A.P., Oksman K., Faria M., Thomas S. and Pothan L.A. (2015) Cellulose, 22, 1075-1090.

[19] Sivakumar R. and Nandhitha G.K. (2017) Legume Res., 40(1), 125-131.

[20] Ozkan S., Sivritepe H., Eris N. and Turhan E. (2005). Sci. Hortic., 106, 568581.

[21] Ashraf M., Athar H.R. Harris P.J.C. and Kwon T.R. (2008). Adv. Agron., 97, 45-110.

[22] Jasik J. and Klerk G.J. (2006) J. Plant Growth Regul., 25, 45-50.

[23] Kathiresan K., Kalyani V. and Gnanarethium J.L. (1984) Field Crops Res., 9, 255-259

[24] Xiong L. and Zhu J.K. (2002) Plant Cell Environ., 25, 131-139.

[25] Radi A., Lange T., Niki T., Koshioka M. and Lange M.J. (2006). Plant Physiol., 140, 528-536.

[26] Saha P., Chatterjee P. and Biswas A.K. (2010) Indian J. Exp. Bio., 48, 593600.

[27] Rezai S.M., Orojloo S.S., Bidabadi V. and Soleimanzadeh M. (2013) Int. J. Agric. Crop Sci., 6, 1235-1238.

[28] Hameed A., Afzal I. and lqbal N. (2010) Seed Sci. Technol., 38, 236-241.

[29] Yildirim E., Turan M. and Guveni I. (2008) J. of Plant Nut., 31, 593-612.

[30] Grattan S.R. and Grieve C. M. (1999) Mineral nutrient acqui-sition and response by plants grown in saline environments. In: Pessarakli M. (ed.): Handbook of Plant and Crop Stress. Marcel Dekker, New York: 203-229

[31] Dutta P. and Bera A. K. (2008) Legume Res., 31, 145148

[32] Aftab T., Masroor M., Khan A., Idrees M., Naeem M. and Hashmi N. (2011) Protoplasma, 248, 601-612.

[33] Singh, B. and Usha K. (2003) Plant Growth Regul., 39, 137-141. 